\title{
THE RELATIONSHIP BETWEEN POLYMORPHISM IN PPARGC1A GENE AND CONFORMATION TRAITS OF SALERS COWS BREED
}

\author{
Department of Ruminant Science, West Pomeranian University of Technology, Szczecin, Poland \\ ${ }^{1}$ Department of Genetics and Animal Breeding, West Pomeranian University of Technology, Szczecin, Poland
}

\begin{abstract}
The study analysed two SNP polymorphisms located in intron $9(1892 \mathrm{~T}>\mathrm{C})$ and the 3'UTR (3359A $>$ C) region of the PPARGC1A gene (GenBank accession number AY321517). The research was conducted in a salers cattle herd. Identification of genotypes of individual individuals was carried out using PCR-RFLP. The $C C$ and $A A$ genotype determined the largest body mass of the analysed animals. Other traits such as cows' habit, muscularity, cross height and chest circumference were most favourable for heterozygous $C T$ individuals concerning the PPARGC1A/Haelll polymorphism. When analysing the relationship between PPARGC1A/Nhel polymorphism and cow habitat characteristics, the genotype was the most beneficial CC. The results obtained were not confirmed statistically.
\end{abstract}

Key words: cow salers, conformation trait, body weight.

\section{INTRODUCTION}

The salers breed comes from France and is resistant to harsh environmental conditions. They are great for breeding in more difficult or extensive feeding conditions. This breed is immune to the disease. Cattle salers belong to late ripening breeds that give birth to small but without a significant share of difficult births. One of the elements included in the assessment of the use-value of animals is the assessment of their habit. Based on it, one can conduct the initial selection of animals, as well as select bulls in a herd of beef cattle (Choroszy et al. 2012). Other authors claim that this type of selection provides additional information about the animal's structure and its production predispositions, thus allowing to direct production in a herd of beef cattle. Therefore, it is such an important factor in breeding work (Barham et al. 2009; Choroszy et al. 2010).

Proliferator-activated receptor peroxisomes-gamma (PPARGC1A, also known as PGC-1a), encoded by the PPARGC1A gene, is a metabolic switch that regulates metabolic pathways via its pleiotropic interactions with nuclear receptors (NR) and other transcription factors other than NR, such as peroxisomal proliferation receptors (PPAR), nuclear respiratory factors (NRF), thyroid hormone (TR) receptors, estrogen-related receptors (ERRs), CCAAT binding (C/EBP) binding proteins and sterol regulatory element (SREBP). PGC-1 $\alpha$ transcriptionally activates the pathways of mitochondrial biogenesis, lipid metabolism and glucose. PPARGC1A, due to its pleiotropic, direct action and significant indirect influence through modulation of cell metabolism, plays a significant and complex role in animal physiology, and learning about this role is of paramount importance for our knowledge of the body's functioning (Li et al. 2014).

Corresponding author: Ewa Czerniawska-Piątkowska, Department of Ruminant Science, West Pomeranian University of Technology, Szczecin, Klemensa Janickiego 29, 71-270 Szczecin, Poland, e-mail: ewa.czerniawska-piatkowska@zut.edu.pl. 
The aim of the study was to estimate the frequency of genotypes and alleles of the polymorphisms studied in the PPARGC1A gene and to determine the possible association of particular genotypes with selected parameters of the salers cattle.

\section{MATERIAL AND METHODS}

The research was carried out in years 2016/2017 on the salers of the breed maintained in the West Pomeranian Voivodeship and fed normalised dietary doses. The individuals were kept in similar environmental conditions, with access to the pasture during spring and summer, and in the winter to hay and haylage. The use value of meat-type beef cattle was assessed in accordance with Commission Decision 2006/427/EC of 20 June 2006, which establishes methods for evaluating the value in use and methods for determining the genetic value of pure-bred breeding animals of the cattle (Decyzja Komisji ustanawiająca metody... DzU WE L 169 z 22.06.2006).

DNA isolation was performed using the MasterPure ${ }^{\mathrm{TM}}$ DNA isolation kit (Epicentre ${ }^{\circledR}$ ) according to the isolation protocol included with the package. Peripheral blood as a DNA isolation material was taken from the zygomatic vein into vacuum tubes containing $K_{3} E D T A$ as an anticoagulant. Genotypes of individual individuals were determined using the PCR-RFL $P$ method. Two SNP polymorphisms localised in intron 9 (1892T $>C)$ and in the 3'UTR region $(3359 A>C)$ of the PPARGC1A gene were analysed (GenBank accession number AY321517). The PCR reaction was carried out using primers in accordance with the work of Khatib et al. (2007). It then digested with the received amplification product with appropriate restriction enzymes. The fragment about intron 9 (195 bp) of bases was digested with an enzyme Haell fragment region, but the 3 'UTR (357 bp) was treated with the enzyme Nhel.

The obtained results were subjected to statistical analysis. An analysis of the relationship between individual genotypes and selected features of cow's habit, cross heights, chest circumference, muscles and body weight of the analysed animals was performed. The statistical analysis of the results was carried out using the Statistica ${ }^{\circledR} 12$ program. The mean values were compared using the Duncan test.

\section{RESULTS}

The frequencies of individual genotypes and alleles for the polymorphisms studied are presented in Table 1. The analysis of the obtained results indicates that the homozygous genotypes $C C(1892 \mathrm{~T}>\mathrm{C})$ and $A A(3359 \mathrm{~A}>\mathrm{C})$ were most frequent and the highest frequency alleles (MAF) were the alleles $C$ and $A$.

Table 1. The genotype and allele frequencies of the studied

\begin{tabular}{lccccc}
\hline Genotype & Number of cows & \multicolumn{2}{c}{ Genotype frequencies } & \multicolumn{2}{c}{ Allele frequencies } \\
\hline PPARGC1A/Haell & 157 & $C C$ & 0.762 & $C$ & 0.881 \\
1892 T>C & 59 & $C T$ & 0.238 & $T$ & 0.119 \\
\hline PPARGC1A/Nhel & 152 & $A A$ & 0738 & & 0.850 \\
3359 A $>$ C & 46 & $A C$ & 0.223 & $C$ & 0.150 \\
& 8 & $C C$ & 0.039 & & \\
\hline
\end{tabular}


Table 2 presented the results of body weight and selected zoom parameters of cows of the salers meat breed. Analysis of the relationship between the PPARGC1A/HaellI genotypes and body weight of the Salers cows showed similar relationships as in the case of PPARGC1A/Nhel polymorphism. Genotype CC (1892 T>C) and AA (3359 A>C) conditioned the highest body mass of the analysed animals. Other features, such as c- blocking of the cows, muscularity, cross-heights and chest circumference, were the most favourable for heterozygous $C T$ individuals with respect to the PPARGC1A/Haelll polymorphism. When analysing the relationships between PPARGC1A/Nhel homozygous $C C$ individuals obtained polymorphism and cows- like features, the highest scores ( 23.5 points). The musculature of the test animals was the best in the case genotype animals $A C$. Individuals with the $C C$ genotype regarding the analysed feature were not significantly affected (the $A A$ genotype was conditioned by the smallest score). Also, the genotype CC animals were characterised by measuring the height of the smallest cross circumferentially and $\mathrm{d}$ in the chest. Cows with $A A$ and $A C$ genotypes obtained slightly higher values of the described zoom measurements.

Table 2. Analysis of the relationship between polymorphism PPARGC1A/Haelll and PPARGC1A/Nhel and the meat performance traits of the salers breed

\begin{tabular}{lcccccc}
\hline Genotype $\begin{array}{c}\text { Number } \\
\text { of cows }\end{array}$ & $\begin{array}{c}\text { Body weight } \\
{[\mathrm{kg}]}\end{array}$ & $\begin{array}{c}\text { Conformation } \\
\text { trait } \\
\text { [point] }\end{array}$ & $\begin{array}{c}\text { Muscularity } \\
{[\text { point] }}\end{array}$ & $\begin{array}{c}\text { Height of } \\
\text { lower back } \\
{[\mathrm{cm}]}\end{array}$ & $\begin{array}{c}\text { Chest girth } \\
{[\mathrm{cm}]}\end{array}$ \\
\hline PPARGC1A/Haelll & & & & & \\
\hline$C C$ & 157 & $589.3 \pm 35.9$ & $22.1 \pm 2.7$ & $15.1 \pm 2.1$ & $146.0 \pm 3.5$ & $202.9 \pm 3.9$ \\
$C T$ & 59 & $572.7 \pm 6.4$ & $22.5 \pm 2.5$ & $15.1 \pm 2.2$ & $146.2 \pm 3.1$ & $203.8 \pm 3.9$ \\
\hline PPARGC1A/Nhel & & & & & \\
\hline$A A$ & 152 & $586.4 \pm 38.3$ & $21.9 \pm 2.7$ & $15.0 \pm 2.2$ & $146.1 \pm 3.3$ & $203.2 \pm 3.9$ \\
$A C$ & 46 & $585.0 \pm 20.6$ & $22.8 \pm 2.4$ & $15.5 \pm 1.9$ & $146.1 \pm 3.8$ & $203.2 \pm 4.3$ \\
$C C$ & 8 & $0 \pm 0$ & $23.5 \pm 1.7$ & $15.3 \pm 1.7$ & $145.5 \pm 3.0$ & $201.5 \pm 2.6$ \\
\hline
\end{tabular}

\section{DISCUSSION}

The analysed polymorphisms in the PPARGC1A gene were also investigated by other authors. For the $1892 \mathrm{~T}>\mathrm{C}$ polymorphism, the frequency of the most common allele ranged from 0.84 in the German Holstein cattle herd (Weikard et al. 2005 ) to 0.56 in the cattle herd and Holstein-Friesian from the Iranian area (Pasendideh et al. 2015). In the case polymorphism 3359, $\mathrm{A}>\mathrm{C}$ demonstrated the most common allele frequencies of 0.88 in a herd of cattle Jersey (Kowalewska-Łuczak et al. 2010) and 0.56 in the herd German Holstein (Weikard et al. 2005).

Polymorphisms in the PPARGC1A gene studied in this study have been studied in relation to various cattle performance traits. The effect of these polymorphisms on milk yield, fat and protein yield in milk was demonstrated (Weikard et al. 2005; Khatib et al. 2007; Komisarek and Dorynek 2009; Boleckova et al. 2012; Pasandideh et al. 2015). However, in the work of Komisarek and Dorynek (2009) and Komisarek and Walendowska (2012) the relations between genotypes of 1892T>C polymorphism and estimated breeding values for 
reproductive traits in Polish HF bulls and reproductive traits of Polish HF cows (respectively) were investigated. Other polymorphisms mapped in the PPARGC1A gene were analysed about cattle growth parameters by $\mathrm{Li}$ et al. (2014). This work demonstrates the association of marked genotypes with features such as body weight and average daily weight gain.

Intensive selection of growth traits is implemented in various beef cattle breeding programs. Due to the growing market requirements for high-quality meat, more and more attention from the breeders is gaining features related to the conformation of the animal body. Body evaluation results are used as selection criteria for inferring the quality of carcases (Shiotsuki et al. 2009). Choroszy et al. (2012) emphasise the importance of breeding programs developed for meat breeds, which assume the selection of the most valuable animals for reproduction. These animals should be characterised by appropriate features relevant to their development, i.e. due to body weight, well-developed skeleton, broad chest, a height at the withers suitable for a given breed, and a significant feature generally referred to as meatiness. The importance of these traits in beef cattle breeding was described in their studies (Adamczyk et al. 2004). It should also be emphasised that the priority in the breeding of beef cattle are proper zoometric parameters, which are responsible for the slaughter value and affecting the proper course of delivery.

\section{CONCLUSIONS}

Analysis of the relationship between the PPARGC1A/Haelll genotypes and body weight of the salers cows showed similar relationships as in the case of PPARGC1A/Nhel polymorphism. Genotype homozygous $C C$ and $A A$ Both polymorphisms conditioned highest body mass analysed animals. Other traits such as cows' habit, muscularity, cross height and chest circumference were most favourable for heterozygous $C T$ individuals concerning the PPARGC1A/Haelll polymorphism. When analysing the relationship between PPARGC1A/ Nhel polymorphism and cows-like traits, the best genetic parameters were found in $C C$ genotypes. The musculature of the tested animals was the most favourable for animals with the $A C$ genotype. In the study, there were no statistically significant differences between the individual genotypes of the tested cattle and the considered features, but thanks to this analysis it was possible to show certain tendencies to achieve lower or higher values of a given trait by an individual with a particular genotype. In conclusion, it can be concluded that the results of the above study can be used in the selection of beef cattle.

\section{REFERENCES}

Adamczyk K., Szarek J., Skrzynski G., Strzetelski J. 2004. Effect of body conformation of crossbred bulls on their slaughter value. Ann. Anim. Sci. 4(2) 253-261.

Barham B., Jones S., Troxel T. 2009. An analysis of beef cattle conformation. University of Arkansas, USA Dep. of Agriculture, 15.

Boleckova J., Matejickova J., Stipkova M., Kyselova J., Barton L. 2012. The association of five polymorphisms with milk production traits in Czech Fleckvieh cattle. Czech J. Anim. Sci. 57(2), 45-53.

Choroszy Z., Choroszy B., Grodzki G., Łopieńska M., Szewczyk A. 2012a. Określenie zależności pomiędzy pokrojem buhajów ras mięsnych a oceną ich wartości użytkowej [Determining the dependence between the cut of bulls of meat breeds and the assessment of their utility value]. Ann. Sci. Zootech. 39(1), 39-46. [in Polish]. 
Choroszy Z., Szewczyk A., Choroszy B. 2010b. Konstrukcja wskaźników wykorzystanych w metodzie oceny wartości użytkowej buhajów ras mięsnych w Polsce [The construction of indicators used in the method of assessing the value in use of meat breeds in Poland]. Ann. Sci. Zootech. 37(2), 123-129. [in Polish]

Decyzja Komisji ustanawiająca metody oceny wartości użytkowej i metody oceny wartości genetycznej zwierząt hodowlanych czystorasowych z gatunku bydła. DzU WE L 169 z 22.06.2006. [in Polish]

Khatib H., Zaitoun I., Wiebelhaus-Finger J., Chang Y.M., Rosa G.J.M. 2007. The association of bovine PPARGC1A and OPN genes with milk composition in two independent Holstein cattle populations. J. Dairy Sci. 90, 2966-2970.

Komisarek J., Dorynek Z. 2009. Effect of ABCG2, PPARGC1A, OLR1 and SCD1 gene polymorphism on Polish Holstein-Friesian bulls. J. App. Genet. 50, 125-132.

Komisarek J., Walendowska A. 2012. Analysis of the PPARGC1A gene as a potential marker for productive and reproductive traits in cattle. Biol. Film 60, 171-174.

Kowalewska-Łuczak I., Kulig H., Kmieć M. 2010. Associations between the bovine PPARGC1A gene and milk production traits. Czech J. Anim. Sci. 55(5), 195-199.

Li M., Liu M., Liu D., Lan X., Lei Ch., Chen H. 2014. The novel coding region of SNPs of PPARGC1A gene and their associations with growth traits in Chinese native cattle. Moth Biol. Rep. 41, 39-44.

Pasandideh M., Mohammadabadi M.R., Esmailizadeh A.K., Tarang A. 2015. Association of bovine PPARGC1A and OPN genes with milk production and composition in Holstein cattle. Czech J. Anim. Sci. 60(3), 97-104.

Shiotsuki L., Silva J.A.II.V., Tonhati H., Albuquerque L.G. 2009. Genetic of the connection of sexual precocity with growth and muscling in Nelore cattle. J. Anim. Sci. 87, 1591-1597.

Weikard R., Kühn Ch., Goldammer T., Freyer G., Schwerin M. 2005. The bovine PPARGC1A gene: molecular characterisation and association of SNP with a variation of milk. Physiol. Genom. 21, 1-13.

\section{ZALEŻNOŚCI MIĘ̇ZY POLIMORFIZMEM GENU PPARGC1A A CECHAMI POKROJU KRÓW RASY SALERS}

Streszczenie. W pracy analizowano dwa polimorfizmy SNP zlokalizowane w intronie 9 (1892T>C) oraz w regionie 3'UTR (3359A>C) genu PPARGC1A (GenBank accession number AY321517). Badania prowadzono w stadzie bydła mięsnego rasy salers. Identyfikacja genotypów poszczególnych osobników prowadzona była przy użyciu PCR-RFLP. Genotypy CC i AA generowały największą masę ciała analizowanych zwierząt. Inne cechy, takie jak pokrój krów, umięśnienie, wysokość w krzyżu oraz obwód klatki piersiowej, najkorzystniejsze były w przypadku osobników heterozygotycznych $C T$, w odniesieniu do polimorfizmu PPARGC1A/Haelll. Z analizy zależności między polimorfizmem PPARGC1A/Nhel a cechami pokroju krów wynika, że najbardziej korzystny był genotyp CC. Otrzymane wyniki nie zostały potwierdzone statystycznie.

Słowa kluczowe: krowy rasy salers, cechy pokroju, masa ciała. 
